\title{
Effect of Growth Media on Plumule Emergence and Early Seedling Growth of Monodora myristica
}

\author{
Chinwe I. Saani ${ }^{1}$, Joshua Kayode ${ }^{2}$, Benson O. Ademiluyi ${ }^{3}$, M. Yoserizal Saragih ${ }^{4}$ \\ 1, 2, ${ }^{3}$ Department of Plant Science and Biotechnology, Ekiti State University, Ado-Ekiti, Nigeria \\ ${ }^{4}$ Universitas Islam Negeri Sumatera Utara, Medan, Indonesia \\ joshua.kayode@eksu.edu.ng,yosesaragih77@gmail.com
}

\begin{abstract}
The study investigated the emergence and early seedling development of Monodora myristica in six different growth media viz: mixture of river sand/top soil, river sand/saw dust, top soil/saw dust, saw dust only, top soil only and river sand only. Results obtained recorded highest percentage germination (63\%) in seeds sown in saw dust only. Early seedling growth was observed for four months. The results of this study showed that seedlings sown in mixture of top soil/saw dust recorded highest mean plant height $(16.83 \mathrm{~cm})$, stem girth $(2.50 \mathrm{~mm})$, and leaf area (46.18cm2) at the end of the experimental time. Seedlings on top soil only had the highest number of leaves (3.89). River sand had the least seedling performance in all the growth parameters examined; plant height $(13.27 \mathrm{~cm})$, stem collar girth $(1.99 \mathrm{~mm})$, leaf length $(8.61 \mathrm{~cm})$, leaf width $(4.77 \mathrm{~cm})$ and leaf area $(30.83 \mathrm{~cm} 2)$. The study established that the \% emergence of Monodora myristica seedlings was best in saw dust medium while mixture of top soil/saw dusts is recommended for enhancing early seedling growth of this plant in the nursery.
\end{abstract}

Keywords: media; plumule; emergence; seedlings; Monodora myristica

\section{Introduction}

Recent initiatives have revealed that plant species with medicinal values are under threats due to a number of reasons. Previous studies have established that the unprecedented removal of forests, especially in developing countries like Nigeria, has resulted in habitat loss and deforestation (Ajayi and Kayode 2020, Ajayi et. al. 2020,). Also a surge in population of herbal remedies and supplements abounds (Sofowora 1993) thus resulting in excessive exploitation of important medicinal plants. The indigenous plant species seems to be the most affected. Kayode (2004) observed that most of the indigenous tree species regenerated poorly and were sparsely populated in the sampling stage. Efforts are now been advocated towards the conservation of the indigenous tree species through domestication.

Monodora myristica is an important indigenous tree species in Nigeria. The tree, an important source of medicine (Iwu 1993), is presently endangered in south western part of the country. Any effort aimed at the domestication of this species must focus at the mass production of its seedlings. Although Mathowa et al. (2014) opined that little is known about growth media suitable for propagating seedlings of indigenous trees yet Baiyeri and Mbah, (2006) had earlier observed that good performance of seedlings in the nursery phase is highly influenced by the nursery growth media.

Growth media are materials on which plants grow and derived their nutrients. Thus growth media are essential for production of quality crops (Keyagha et al, 2016) and provide sufficient anchorage or support to plants. Media composition used influence the quality of seedlings (Wilson et al., 2001). Media composition used influence the quality of seedlings (Wilson et al., 2001), the rate of growth and the time taken for plants to attain maturity (Okunomo et al., 2006).

Consequent on the above, the study being reported aimed to investigate the most appropriate nursery medium to enhance early seedling growth of Monodora myristica. 


\section{Materials and Methods}

The experiment was carried out at the screen house of the Department of Plant Science and Biotechnology, Adekunle Ajasin University, Akungba Akoko, Nigeria. Monodora myristica seeds were extracted from pods and air dried under room condition. A total of 180 viable seeds were selected from these seeds and used for the experiments. Also, 18 planting pots, which were subdivided into six groups, were used for the experiments.

Consequent on the above, A group of 3 pots were filled with river sand and top soil, as Treatment A, another group filled with river sand and saw dust as Treatment B, Treatments C, $\mathrm{D}, \mathrm{E}$ and $\mathrm{F}$ were filled with top soil and saw dust (1:1 ratio), saw dust only, river sand only and top soil only respectively. 10 viable seeds of Monodora myristica were planted in each pot.

Seedling emergence was observed from first day and continued for two weeks. Emergence percentage and coefficient of velocity was determined. Assessment of growth parameters commenced 4 weeks after emergence. Growth parameters assessed were plant height, stem collar diameter, number of leaves, leaf length, leaf width and leaf area measured at two-week interval for four months. The data collected were subjected to analysis of variance (ANOVA) using Duncan Multiple Range Test (DMRT).and least significant difference (LSD) used to separate the means at $\mathrm{p} \leq 0.05$.

\section{Results and Discussion}

Table 1 shows the effect of the different growth media on \% seedling emergence and coefficient of velocity of $M$. myristica. Treatment D (i.e. seeds planted on sawdust only) had the highest value on the \% emergent (63\%), followed by Treatment B (i.e. seeds planted on combined river sand and sawdust) with $57 \%$ emergent. The least emergent occurred in Treatment F (40\%) (i.e. seeds planted on top soil only). Also, the highest speed of germination $(\mathrm{CoV})$ occurred in Treatment $\mathrm{D}$ (78) followed by Treatment B while the least was obtained in Treatment F (52).

Table 1. Effect of Different Growth Media on Percentage Seedling Emergence and Coefficient of Velocity of $M$. myristica

\begin{tabular}{|lcc|}
\hline Treatment & \% Emergence & Coefficient of velocity \\
\hline A & 47 & 65 \\
B & 57 & 72 \\
C & 47 & 56 \\
D & 63 & 78 \\
E & 53 & 70 \\
F & 40 & 52 \\
\hline
\end{tabular}

Table 2 revealed that in all the treatments, plant heights increased with the increase in the experimental time. Treatment $\mathrm{C}$ had the highest plant height at the end of the experiment $16.83 \mathrm{~m}$ (Month 4) while the least was obtained in Treatment E (13.27). At month 1 of the 
experiment, the plaint heights in Treatments A, B, C, D and E were not significantly different from one another. Also plant heights obtained in Treatments F, B and C were not significantly different from one another but at the end of the experiment (Month 4), plant heights in all the treatments, with the exception of Treatments A and F were significantly different from one another.

Table 2. Effect of Different Growth Media on Plant Height of Monodora myristica

\begin{tabular}{|lcccc|}
\hline Treatment & \multicolumn{4}{c|}{ Plant Height $(\mathrm{cm}) /$ Experiment Time (in Month)* } \\
& 1 & 2 & 3 & 4 \\
\hline A & $6.67 \pm 0.23 \mathrm{a}$ & $13.03 \pm 3.33 \mathrm{~b}$ & $15.30 \pm 0.10 \mathrm{c}$ & $15.83 \pm 0.03 \mathrm{~d}$ \\
B & $6.73 \pm 0.07 \mathrm{ab}$ & $12.27 \pm 0.03 \mathrm{ab}$ & $13.80 \pm 0.10 \mathrm{~b}$ & $14.57 \pm 0.15 \mathrm{c}$ \\
C & $6.87 \pm 0.15 \mathrm{ab}$ & $13.97 \pm 0.20 \mathrm{~b}$ & $16.30 \pm 0.12 \mathrm{~d}$ & $16.83 \pm 0.18 \mathrm{e}$ \\
D & $6.67 \pm 0.19 \mathrm{a}$ & $11.80 \pm 0.10 \mathrm{a}$ & $13.12 \pm 0.42 \mathrm{ab}$ & $14.07 \pm 0.03 \mathrm{~b}$ \\
E & $6.53 \pm 0.18 \mathrm{a}$ & $11.40 \pm 0.15 \mathrm{a}$ & $12.67 \pm 0.12 \mathrm{a}$ & $13.27 \pm 0.17 \mathrm{a}$ \\
F & $7.23 \mathrm{v} 0.09 \mathrm{~b}$ & $13.47 \pm 0.15 \mathrm{~b}$ & $15.30 \pm 0.06 \mathrm{c}$ & $15.93 \pm 0.15 \mathrm{~d}$ \\
\hline
\end{tabular}

*Values are means \pm standard error; Means with similar superscripts within a column are not significantly different from one another at $\mathrm{P} \leq 0.05$

Results obtained in the girths (Table 3) of the seedlings were similar to that of the plant heights. The girths increased with the increase in the experimental time in all the treatments. However there were no significant differences in the girths obtained in all the treatments throughout the experimental period. Treatment $\mathrm{C}$ had the highest girth values at the commencement (2.09) and final experimental time (2.50) while the least values at the commencement and final experimental times were obtained in Treatments E (1.80 and 1.99 respectively).

Table 3. Effect of Different Growth Media on Stem Girth of Monodora myristica

\begin{tabular}{|lcccc|}
\hline Treatment & \multicolumn{3}{c|}{ Stem Girth (mm) / Experiment Time (in Month) * } \\
& 1 & 2 & 3 & 4 \\
\hline A & $1.87 \pm 0.10 \mathrm{a}$ & $2.06 \pm 0.09 \mathrm{a}$ & $2.10 \pm 0.12 \mathrm{a}$ & $2.25 \pm 0.09 \mathrm{a}$ \\
B & $1.83 \pm 0.16 \mathrm{a}$ & $1.94 \pm 0.17 \mathrm{a}$ & $2.03 \pm 0.15 \mathrm{a}$ & $2.13 \pm 0.15 \mathrm{a}$ \\
C & $2.09 \pm 0.12 \mathrm{a}$ & $2.20 \pm 0.10 \mathrm{a}$ & $2.23 \pm 0.12 \mathrm{a}$ & $2.50 \pm 0.06 \mathrm{a}$ \\
D & $1.81 \pm 0.1 \mathrm{a}$ & $1.91 \pm 0.12 \mathrm{a}$ & $1.97 \pm 0.18 \mathrm{a}$ & $2.05 \pm 0.15 \mathrm{a}$ \\
E & $1.80 \pm 0.1 \mathrm{a}$ & $1.88 \pm 0.00 \mathrm{a}$ & $1.93 \pm 0.03 \mathrm{a}$ & $1.99 \pm 0.00 \mathrm{a}$ \\
F & $2.01 \pm 0.05 \mathrm{a}$ & $2.13 \pm 0.07 \mathrm{a}$ & $2.17 \pm 0.07 \mathrm{a}$ & $2.40 \pm 0.06 \mathrm{a}$ \\
\hline
\end{tabular}

*Values are means \pm standard error; Means with similar superscripts within a column are not significantly different from one another at $\mathrm{P} \leq 0.05$ 
The effect of different growth media on number of leaves of Monodora myristica was (Table 4) was similar to those obtained on stem girths. In all the treatments, the girths increases with the increase in the experimental time and there were no significant differences in the number of leaves of the seedlings obtained in all the treatments throughout the experimental time.Treatment $\mathrm{B}$ has the highest number of leaves at the commencement of the experiment (3.22) while the highest number of leaves at final experimental time was obtained in Treatment F (3.89). The least number of leaves (2.90) at the commencement of the experiment was obtained in Treatment $\mathrm{E}$ and least number of leaves at the final experimental time (3.67) was obtained in Treatments B, D and E.

Table 4. Effect of Different Growth Media on Number of Leaves of Monodora myristica

\begin{tabular}{|lcccc|}
\hline Treatment & \multicolumn{4}{c}{ Number of Leaves / Experiment Time (in Month) * } \\
& 1 & 2 & 3 & 4 \\
\hline A & $3.23 \pm 029 \mathrm{a}$ & $3.33 \pm 0.20 \mathrm{a}$ & $3.67 \pm 0.13 \mathrm{a}$ & $3.78 \pm 0.13 \mathrm{a}$ \\
B & $3.22 \pm 0.10 \mathrm{a}$ & $3.33 \pm 0.00 \mathrm{a}$ & $3.56 \pm 0.00 \mathrm{a}$ & $3.67 \pm 0.00 \mathrm{a}$ \\
C & $3.11 \pm 0.33 \mathrm{a}$ & $3.22 \pm 0.23 \mathrm{a}$ & $3.56 \pm 0.23 \mathrm{a}$ & $3.78 \pm 0.23 \mathrm{a}$ \\
D & $3.11 \pm 0.10 \mathrm{a}$ & $3.22 \pm 0.2 \mathrm{a}$ & $3.45 \pm 0.20 \mathrm{a}$ & $3.67 \pm 0.30 \mathrm{a}$ \\
E & $2.90 \pm 0.10 \mathrm{a}$ & $2.90 \pm 0.10 \mathrm{a}$ & $3.34 \pm 0.23 \mathrm{a}$ & $3.67 \pm 0.20 \mathrm{a}$ \\
F & $3.11 \pm 0.13 \mathrm{a}$ & $3.33 \pm 0.13 \mathrm{a}$ & $3.67 \pm 0.13 \mathrm{a}$ & $3.89 \pm 0.13 \mathrm{a}$ \\
\hline
\end{tabular}

*Values are means \pm standard error; Means with similar superscripts within a column are not significantly different from one another at $\mathrm{P} \leq 0.05$

Table 5 shows that the leaf area increases with the increase in the experimental time. Treatment A has the least leaf area $\left(11.97 \mathrm{~cm}^{2}\right)$ at the commencement of the experiment while Treatment $\mathrm{E}$ has the least leaf area $\left(30.83 \mathrm{~cm}^{2}\right)$ at the final experimental time. Treatment $\mathrm{F}$ has the highest leaf area at the commencement and Treatment $C\left(46.18 \mathrm{~cm}^{2}\right)$ at the final experimental time. Statistical analyses revealed that at the commencement of the experiment, Treatments A, B and E as well as Treatments B, C, D and E were not significantly different from one another but at the final experimental time, Treatments B, D and E as well as Treatments , A, B, D and F were not significantly different. 
Table 5. Effect of Different Growth Media on Leaf Area of Monodora myristica

\begin{tabular}{|lcccc|}
\hline Treatment & \multicolumn{4}{c|}{ Leaf area $\left(\mathrm{cm}^{2}\right)$ / Experiment Time (in Month)* } \\
& 1 & 2 & 3 & 4 \\
\hline A & $11.97 \pm 0.54 \mathrm{a}$ & $21.22 \pm 0.90 \mathrm{a}$ & $29.94 \pm 0.99 \mathrm{a}$ & $36.17 \pm 1.17 \mathrm{~b}$ \\
B & $12.56 \pm 2.07 \mathrm{ab}$ & $20.38 \pm 1.37 \mathrm{a}$ & $29.04 \pm 1.43 \mathrm{a}$ & $32.72 \pm 1.40 \mathrm{ab}$ \\
C & $13.48 \pm 1.70 \mathrm{~b}$ & $28.13 \pm 2,09 \mathrm{~b}$ & $40.24 \pm 2.60 \mathrm{~b}$ & $46.18 \pm 3.12 \mathrm{c}$ \\
D & $13.50 \pm 1.25 \mathrm{~b}$ & $20.01 \pm 0.79 \mathrm{a}$ & $27.19 \pm 2.27$ & $32.60 \pm 1.93 \mathrm{ab}$ \\
E & $12.95 \pm 0.0 \mathrm{ab}$ & $19.90 \pm 0.79 \mathrm{a}$ & $28.23 \pm 0.99 \mathrm{a}$ & $30.83 \pm 0.73 \mathrm{a}$ \\
F & $16.07 \pm 1.70 \mathrm{c}$ & $24.43 \pm 1.20 \mathrm{ab}$ & $30.49 \pm 2.29 \mathrm{a}$ & $36.83 \pm 1.44 \mathrm{~b}$ \\
\hline
\end{tabular}

*Values are means \pm standard error; Means with similar superscripts within a column are not significantly different from one another at $\mathrm{P} \leq 0.05$

The emergence of Monodora myristica was affected by various growth media used in this study. Seeds of Monodora myristica sown in saw dust only had the highest emergence rate when compared to other growth media. This supports the work of Peter-Onoh et al., (2014) which reported that saw dust improved early and high number of Monodora myristica in the nursery, and that of Aderounmu et. al. (2019) on Afzelia africana. Saw dust texture which is much lighter in weight compared to soil and provide high water holding capacity, good aeration, and stimulate warmth could have facilitated germination. According to Arunachalam et al. (2003) moisture and aeration play key roles in germination of seeds as they enhance metabolic activities in the seeds.

The mixture of river sand and saw dust had the next higher emergence. Although river sand is poor in nutrients, Isirimal et al., (2003) maintained that they are ideal for seed germination as the germinating embryo depend on stored nutrients within the seeds for their initial growth and other metabolic activities. Also the saw dusts in the mixture tend to provide nutrients deficient in the river sand. The comparison of the results with other studies tends to suggest the growth media preference varied form one plant to another. For example, the performance of saw dusts experienced in this study is in line with the results of Omokhua et. al. (2015) on T. ivorensis. Also the good performance of river sand and saw dusts is expected when the emergence performance in Vitellaria paradoxa in river sand is taken into consideration Asinwa et al. 2010).

Elsewhere in studies conducted by Okunowo (2010), high germination percentage was obtained in top soil in Parkia bicolor, T. ivoresis (Agboola and Adedire 2002), Dacryodes edulis and Persia Americana (Okunomo (2000, 2014). But in studies conducted by Dickens (2011) on Irvingia wombola and those of Anber (2010) conducted on Bauhinia variegate and Delonix regia, highest germination percentages were obtained in river sand. Also, other factors might affect the germination and emergence of seedlings in plant species. These might include seed size and location. For example, Studies by Omokhua et. al. (2015) and Kehinde (2019), highest germination were obtained in T. ivorensis in saw dusts medium but in the study conducted by Agboola and Adedire (2002) on the same plant, highest germination occurred in the top-soil medium.

The results obtained on plant height, stem girths and leaf area revealed that the heights, stem girths and leaf area increased with increase in the experimental time in all the growth media used in this study. However, the best growth was obtained in the mixture of top-soil and saw dusts medium. The mixture is laden with growth inducing properties. The top soil is reach in all the nutrients that plants need to survive while the saw-dusts component ensures 
the loose component of the medium. The looseness allows the plants roots to spread easily and have more access to nutrients and water, which helps build a strong root system for plant growth. Previous assertions by Kramer and Kozlowski (1979) as well as Okunowo et al. (2009) revealed that nutrient availability enhanced the activity of meristemic tissues and thus improve the growth of plants in height and diameter. Owston (1973) asserted that saw dusts contains all the minor elements essential to plant growth.

The results obtained in this study on plant height are almost similar to that obtained by Omokhua et. al. (2015) on T. ivorensis and Anber (2010) on B. variegate where the best heights were obtained from the top-soil medium. However, comparison with other studies also revealed that height and girth performances in growth media may vary from one plant to another. For example Okunomo (2010) obtained the best height and girth in P. bicolour in poultry droppings. Similarly in this study, the highest number of leaves was obtained in topsoil medium. The study by Omokhua et. al. (2015) also obtained the highest number of leaves in top-soil medium in T. ivorensis but in P. bicolour, Okunomo (2010) obtained the highest number of leaves in poultry droppings medium.

\section{Conclusion}

The study established though Monodora myristica seedlings grow in various growth media, the best result was obtained in medium made up of mixture of top soil and saw dust. Thus, it is being suggested that Monodora myristica seedlings should be raised in this medium at the nursery stage.

\section{References}

Aderounmu, A. F., Asinwa, I. O. and Adetunji, A. O. (2019). "Effects of Seed Weights and Sowing Media on Germination and Early Growth of Afzelia Africana". Journal of Agriculture and Ecology Research International 19(3): 1-11.

Agboola, P.A. and Adedire, M.O. (2002). "Response of treated dormant seeds of tropical tree species of germination promoters". Nigerian Journal of Botany 11: 103-110.

Ajayi, I. K. and Kayode, J. (2020). A Survey of Fruit Trees Species in an Urban Community in Ekiti State, Nigeria. Budapest International Research in Exact Sciences Journal (BirEx-Journal) 2(3), 280-290.

Ajayi, I. K., Kayode, J. and Ademiluyi, B. O. (2020). Study on Urban Trees in Ekiti State University, Ado Ekiti, Nigeria: 1. Structure and Composition. Budapest International Research in Exact Sciences Journal (BirEx-Journal) 2 (2), 147 -156

Anber, M. A. H. (2010). "Improving seed germination and seedling growth of some economically important trees by seed". Forest Sci., 7(3): 371-382.

Anurachalam, A., Khan, M. I. and Singh, N. D. (2003). "Germination growth and biomass accumulation as influenced by seed size in Mesua ferra L". Turkish Journal of Botany 27:343-348.

Asinwa I. O., Kazeem-Ibrahim, F., Olaifa, K. A. and Asabia, L. O. (2019). "Storage potentials and influence of moisture contents on germination of Vitellaria paradoxa C.F. Gaertn”. Journal of Research in Forestry and Wildlife \& Environment 11(2): 7479.

Baiyeri, K.P. and Mbah, B.N. (2006). "Effects of soiless and soil -based nursery media on seedling emergence, growth and response to water stress of African breadfruit (Treculia africana Decne)". African Journal of Biotechnology 5(15):1405-1410. 
Dickens, D. (2011). "Effect of propagation media on the germination and seed performance of Irvingia wombolu (Vermoesen)". American Journal Biotechnology and Molecular Sciences. 21593701. [ISSN print: 21503698] DOI:10525/ajbms.2011.1.2.51.56 Cscience Hu, Available:http://www.scihub.org/AJBMS20 11

Isirimah, A.O., Dickson, O. and Igwe, C. (2003). "Introductory Soil Chemistry and Biology". Osia Publishers Ltd. Diobu, Port Harcourt Nigeria, pp: 187.

Iwu, M. M. (1993). "Handbook of African medicinal plants". CRC Press, Bole Ralvon and Arbour, Tokyo.

Kayode, J. (2004). "Conservation perception of endangered spices by rural dweller of Ekiti State Nigeria". Journal of Sustainable Forestry 29 (5), 477-485.

Kehinde, B. R. (2019). "Effects of Different Sowing Media on Germination and Early Growth of Terminalia ivorensis (A. Chev.)". Continental J. Applied Sciences 14 (1): 8 15 DOI: $10.5281 /$ zenodo. 2558095

Keyagha, E.R, Uwakwe, J.C., Cookey, C.O., Emma-Okafor, L.C., Obiefuna, J.C., Alagba, R.A., Ihejirika, G. O. and Ogwudire, V. E. (2016). "Effect of different growth media on the growth and development of Irvingia wombulu in Owerri, South Eastern Nigeria". International Journal of Agriculture and Rural Development 19(1): 25692575.

Kramer, P.T. and Kozlowski, T.T. (1979). "Physiology of woody plants". Academic Press, New York. 811pp.

Mathowa, T., Bosenakitso, M., Majeremane, W., Mpofu, C. and Legwaila, G. M. (2014). "Effect of growing media on seedling growth of African baobab (Adansonia digitata L.)". International Journal of Advanced Research in Biological Science 1(7):94-104

Okunowo, K., Ureigbo, U.N. and Opute, H.O. (2006). "The Effect of Soil amendment on the performance of Gambaya albida (Linn) seedlings". Agricultural Journal 1(4): 262265.

Okunowo, K., Ogisi, D.O., and Bosah, B.O (2009). "Effect of growth media on germination and seedling growth of Persea Americana (Mill)". Journal of Food, Agriculture and Environment 7(1):111-113.

Okunomo K. (2010). "Germination and seedling growth of Parkia bicolor (A. Cheu) as influenced by nursery techniques". African Journal of General Agriculture 6(4).

Omokhua, G. E., Ogu, A. and Oyebade, B.A. (2015). "Effects of Different Sowing Media on Germination and Early Seedling Growth of Terminalia ivorensis (A.Chev.)". International Journal of Scientific and Technology Research 4 (3): 119-122.

Owston, P.W. (1973). "Cultural techniques for growing containerized seedlings". Western For Nursery Counc. and Intermountain For. Nurseryman's Assoc. Proc. 1972:32-41.

Peter-Onoh, C. A., Obiefuna, J.C., Ngwuta, A.A., Onoh, P.A., Ibeawuchi, I. I., Ekwugba, E. U., Emma-Okafor, L.C., Nze, E.O., Orji, J.O and Onyeji, E. C. (2014). "Efficacy of Five Different Growth Media on Seedling Emergence and Juvenile Phenology of Monodora myristica (Africa nutmeg, Ehuru) in the nursery". IOSR Journal of Agriculture and Veterinary Science 7(5, 1): 60-63.

Sofowora, A. (1993). "Medicinal plants and traditional medicine in Africa". Spectrum Books, Ibadan, Nigeria, p. 150

Wilson, S. B., Stoffella, P. J. and Graetz, D. A. (2001). "Use of compost as a media amendment for containerized production of two subtropical perennials". J. Environ. Hortic. 19:37-42. 